\title{
Bidens mosaic virus: detecção via RT-PCR e identificação de Galinsoga parviflora como um novo hospedeiro natural do vírus.
}

\author{
Márcio Martinello Sanches*; David Marques de Almeida Spadotti; Bruno Rossito De Marchi; Marcelo Agenor \\ Pavan; Renate Krause-Sakate.
}

Departamento de Produção Vegetal, Setor de Defesa Fitossanitária, UNESP, Faculdade de Ciências Agronômicas, CEP 18603-970, Botucatu,SP. *Parte da Tese de Doutorado do primeiro autor

Autor para correspondência: Renate Krause Sakate (renatekrause@ fca.unesp.br)

Data de chegada: 23/03/2010. Aceito para publicação em: 06/12/2010.

\section{RESUMO}

Sanches, M. M.; Spadotti, D.M. de A.; De Marchi, B.R.; Pavan, M.A.; Krause-Sakate, R. Bidens mosaic virus: detecção via RT-PCR e identificação de Galinsoga parviflora como um novo hospedeiro natural do vírus. Summa Phytopathologica, v.36, n.4, p.304-307, 2010.

O Bidens mosaic virus (BiMV) é uma espécie tentativa do gênero Potyvirus, que infecta alface (Lactuca sativa). Na ausência de métodos eficientes para diagnose deste vírus, o objetivo do trabalho foi a síntese de oligonucleotídeos específicos e sua otimização em testes de RT-PCR em uma só etapa, partindo-se de extrações de RNA total. Os oligonucleotídeos 8851sens (5'AGG CAG TTC GCA CGG CAT AC 3') e 9211 ant (5' CTT CAT CTG GAT GTG TGC TTC 3') permitem a eficiente detecção do vírus e possibilitaram a descoberta de uma nova hospedeira do vírus, a planta Galinsoga parviflora, comumente encontrada em canteiros de produção comercial de alface.

Palavras-chave adicionais: Potyvirus, alface, BiMV

\section{ABSTRACT}

Sanches, M. M.; Spadotti, D.M. de A.; De Marchi, B.R.; Pavan, M.A.; Krause-Sakate, R. Bidens mosaic virus: detection by RT-PCR and identification of Galinsoga parviflora as a new natural host of the virus. Summa Phytopathologica, v. n. p., 2010. Summa Phytopathologica, v.36, n.4, p.304-307, 2010.

Bidens mosaic virus (BiMV) is a tentative species of the genus Potyvirus and infects lettuce (Lactuca sativa). In the absence of efficient methods for the diagnosis of the virus, the objective of this work was to develop specifics primers for a one-step RT-PCR test using total RNA. The primer pairs 8851 sens (5'AGG CAG
TTC GCA CGG CAT AC 3') and 9211 ant (5' CTT CAT CTG GAT GTG TGC TTC 3') were considered very efficient for the detection of BiMV and the virus was found naturally infecting Galinsoga parviflora, a new host of BiMV, commonly found in commercial lettuce crops.

Keywords: Potyvirus, lettuce, BiMV

O Bidens mosaic virus (BiMV) é uma espécie tentativa do gênero Potyvirus, verificada infectando fumo (Nicotiana tabacum), girassol (Helianthus annus), ervilha (Pisum sativum), Chenopodium quinoa, C. amaranticolor, Zinia elegans, picão (Bidens pilosa $)(1,4,6)$ e alface (3). Por meio de análises na região codificadora da proteína capsidial de um isolado de BiMV proveniente de ervilha e outro de picão, foi proposto recentemente que o BiMV poderia ser uma estirpe do Potato virus Y, PVY(5).

Apesar de já ter sido relatado há algum tempo em alface (3) é um vírus pouco estudado na cultura, principalmente pela falta de um teste de detecção eficiente para o vírus. Antissoro contra um isolado de BiMV proveniente de alface já foi produzido, porém em PTA-ELISA a sensibilidade de detecção do vírus a partir de alface foi baixa, tendo sido somente boa a partir de plantas de Chenopodium quinoa infectadas pelo vírus (9). Em alface o vírus causa sintomas semelhantes ao Lettuce mosaic virus (LMV) e Lettuce mottle virus (LeMoV), sendo difícil sua identificação por meio de métodos biológicos (8).

$\mathrm{Na}$ ausência de métodos moleculares de diagnose para o BiMV, o objetivo deste trabalho foi a elaboração de oligonucleotídeos específicos para este vírus e sua otimização em testes de RT-PCR em uma só etapa.

Para extração do RNA total utilizou-se o método de Bertheau et al. (2). Os oligonucleotídeos foram desenhados a partir da sequência anteriormente obtida de alface (8) e de outras depositadas no Gen Bank provenientes de ervilha e B. pilosa (5). As sequências foram analisadas pelo programa BLAST n (www.ncbi.nlm.gov/ blast/) e Mega versão 3.1 (7).

Os oligonucleotídeos obtidos foram denominados 8851sens (5'AGG CAG TTC GCA CGG CAT AC 3') e 9211 ant (5' CTT CAT CTG GAT GTG TGC TTC 3’) e amplificaram eficientemente o fragmento de $360 \mathrm{bp}$ (Figura 1), a partir de amostras de alface, picão preto e Galinsoga parviflova através de RT-PCR em uma única etapa utilizando-se o Kit PCR Master Mix (Promega). Para um volume de $25 \mu \mathrm{l}$ adicionou-se: $12,5 \mu \mathrm{l}$ de PCR Master Mix 2X, $100 \mathrm{M}$ de cada oligonucleotídeo, 1 unidade da transcriptase reversa AMV (Promega a 15 unidades/ L), 2,5 $\mu$ l de RNA e água livre de RNAses para completar o volume de $25 \mu \mathrm{l}$. O ciclo utilizado 


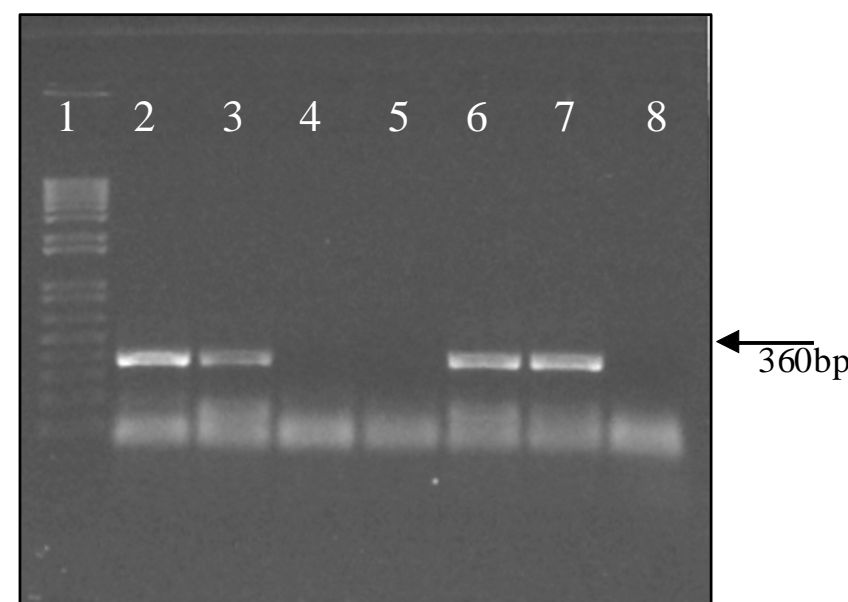

Figura 1. RT-PCR com os oligonucleotídeos 8851 sens/9211ant. (1) Marcador 1KB; (2) Alface infectada com BiMV; (3) Bidens pilosa infectada com BiMV; (4) Alface sadia; (5) Bidens pilosa sadia; (6) Galinsoga parviflova infectada com BiMV; (7) Alface infectada como controle positivo; (8) Controle negativo.

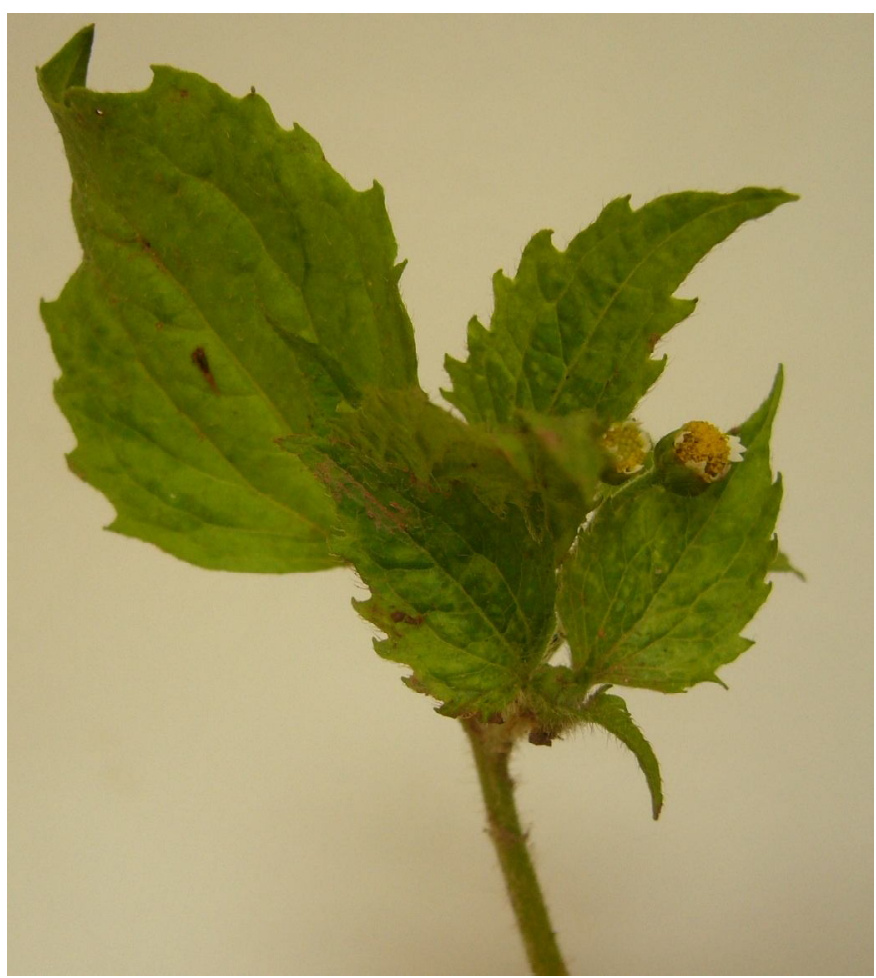

Figura 2. Galinsoga parviflora infectada com BiMV mostrando sintomas de mosaico. consistiu em 30 minutos a $42^{\circ} \mathrm{C}$, seguido de 5 minutos à $95^{\circ} \mathrm{C}, 40$ ciclos de $92^{\circ} \mathrm{C} / 20$ segundos, $56^{\circ} \mathrm{C} / 40$ segundos e $72^{\circ} \mathrm{C} / 60$ segundos, finalizando com $72^{\circ} \mathrm{C} / 10$ minutos.

$\mathrm{O}$ sequenciamento dos fragmentos de amostras provenientes de picão apresentaram identidade de aminoácidos de $99 \%$ e de nucleotídeos de 97 a 99\% com outros isolados de BiMV. Os oligonucleotídeos estão sendo utilizados eficientemente na detecção do BiMV a partir de alface, tendo sido possível também a descoberta de uma nova hospedeira do vírus, a planta Galinsoga parviflora, conhecida popularmente como fazendeiro. Plantas de G. parvilhora naturalmente infectadas apresentam um mosaico discreto nas folhas mais novas (Figura 2) e devem ser consideradas como fonte de inoculo do vírus no campo.

\section{Agradecimentos}

Os autores agradecem à FAPESP o auxílio concedido (processo 2007/04162-4).

\section{REFERÊNCIAS BIBLIOGRÁFICAS}

1. Berger, P.H. ; Adams, M.J. ; Barnett, O.W. ; Brunt, A.A. ; Hammond, J. ; Hill, J.H. ; Jordan, R.L. ; Kashiwazaki, S. ; Rybicki, E. ; Spence, N. ; Stenger, D.C. ; Ohki, S.T. ; Uyeda,VI. ; Van Zaayen, A. ; Valkonem,J. ; Vetten, H.J. In: Virus Taxonomy. Eight Report of the InternationalCommittee on the Taxonomy of Viruses. San Diego:Elsevier; Academic Press, 2005. 1257 p.

2. Bertheau, Y.; Frechon, D.; Toth, I.K.; Hyman, L.J. DNA amplification by polymerase chain reaction (PCR). IN: Perombelon, M. C. M.; van der Wolff. J. M. Methods for the detection and quantification of Erwinia carotovora subsp. atroseptica on potatoes. Dundee:Scottish Crop Research Institute Occasional Publication, 1998.

3. Costa, A.S.; Kitajima, E.W. Virus do mosaico do picão ataca girassol. "O Estado de São Paulo", São Paulo, 30 nov. 1966. Suplemento Agrícola, p.12-13.

4. Hasegawa, J.M. Identificação e caracterização de isolado de Bidens mosaic virus e triagem de alface para resistência. 2006. $44 \mathrm{f}$. . Dissertação (Mestrado em Agronomia/ Proteção de Plantas)Faculdade de Ciências Agronômicas, Botucatu.

5. Inoue-Nagata, A.K.; Oliveira, P.A.; Dutra, L.S.; Nagata, T. Bidens mosaic virus is a member of the Potato virus $\mathrm{Y}$ species. Virus Genes, Dordrecht, v.33, p.45-49, 2006.

6. Kitajima, E. W.; Carvalho, A. M. B.; Costa, A. S. Morfologia do vírus do mosaico do picão. Bragantia, Campinas, v. 20, n. 13, p. 503-512, 1961.

7. Kumar, S.; Tamura, K; Nei, M. MEGA3:Integrated software for Molecular Evolutionary Genetics Analysis and sequence alignment. Briefings in Bioinformatics, Oxford, v. 5, p. 150-163, 2004.

8. Sanches, M.M.; Suzuki, G.S.; Rosa, R.A.C.; Pavan, M. A.; KrauseSakate, R. Caracterização de um isolado de Bidens mosaic virus proveniente de alface. Summa Phytopathologica, Botucatu, v. 34, supl., p. 25, 2008.

9. Spadotti, D.M.A.; Suzuki, G.S.; Sanches, M.M.; Krause-Sakate, R.; Pavan, M.A. Detecção do Bidens mosaic virus através de PTA-ELISA com antissoro produzido a partir de um isolado de alface. Fitopatologia Brasileira, Brasília, v.33, supl., p.290. 2008. 